\title{
Urban renewal as a lever for action in urban policy to make social housing districts more attractive
}

\author{
K. Schaeffer \\ Laboratoire Politiques Publiques, Action Politique, Territoires (PACTE) \\ Université Grenoble Alpes, Grenoble, France
}

\begin{abstract}
Social housing districts in French suburbs have undergone increasing pauperisation and a trend toward marginalisation for decades. The population is facing social issues, which are associated with the negative image of the districts. Altering large housing areas and transforming the inhabitants' living conditions have been the primary goals in the French urban policy carried out since 2003. This urban policy has fundamentally intervened in these districts, primarily focusing on their built heritages and on their urban structures. The goal was to reintroduce these districts within the cities, to create social diversity in the housing and to diversify the functions. This urban policy was aimed at changing the image of these districts and at systematically taking the opposite view of a stigmatising modern architecture. The state has chosen urban renewal as the lever for action of its urban policy, in order to change the negative representations of these districts and, especially, to make them attractive to the less vulnerable members of society. Collecting the inhabitants' social representations and analysing their comments about the results of the projects make it possible to assess how urban renewal can affect the image of these areas. With the social representations of the renewed districts, we can evaluate whether this policy actually helped to make social housing districts attractive and whether these areas improve people's quality of life or a place that people just put up with. The action of the urban policy in large housing areas has been aimed at re-evaluating the representations of these districts. Urban projects constantly mobilise social representations in order to justify town planning actions. Trying to identify these representations enables one to understand how the perceptions are constructed and how they change. It also helps to assess the extent to which the urban policy interventions on urban and
\end{abstract}


architectural forms have had an impact. This identification is carried out through field investigations after theoretically analysing data from district barometers, from evaluations and others. The comments are collected among the newcomers (newly constructed housing programmes) by means of semi-structured interviews about the urban project. Choosing this category of inhabitants helps in assessing how attractive the area is and also in bringing out the image of the area before its urban renewal, what has induced the newcomers to move in and how they perceive the area now. Analysing the content of the comments and identifying the representations of the particular sites underline the strong and weak points of the urban project, and also show how difficult it is for this policy to change the image of those districts. Social representation is an assessing tool but it can become an action tool in district renewal projects, fostering a participatory approach, from the moment it has been taken into account and it can be reinterpreted within the project.

Keywords: urban renovation projects, social representation, social housing.

\section{Introduction}

The production of large housing areas from the 1950s to the 1970s has definitely shaped urban and architectural landscapes in France. They were associated with the negative image of large housing areas; therefore their inhabitants' social issues have only increased the stereotypes on these districts over the decades.

Since then, the state has developed a whole body of iconography that supports the actions of the urban policy in large housing areas, showing their decay, the physical degradation of the buildings and the "uneasiness" in the suburbs. Hence a range of terminology referring to these districts has accompanied and justified the restoration campaign since 2003.

In 2003, the Framework Act for Town Planning and Urban Renewal made it possible to intervene in-depth in large housing districts, primarily focusing on their built heritages and on their urban structures. The goal was to reintroduce these districts within the cities, to create social diversity in housing and to diversify the functions.

This urban policy was aimed at changing the image of these districts and at systematically taking the opposite view of a stigmatising modern architecture.

This approach used a descriptive vocabulary from the medical register [1], underlining the pathogenic characteristics of those places and of their inhabitants.

The construction of a specific image about suburban neighbourhoods has enabled the demolition of large housing areas and the whole policy carried out by the state and the town operators.

There was already a monopoly on controlling that image in 1945 , in order to promote the policy of the state based on land use planning and urban planning [2]. It has once again justified the large renewal undertaking in these districts.

Urban renewal has become the lever for action of French urban policy to change the negative representations of these districts and especially to make them attractive to the less vulnerable members of society. 
This reflection firstly exposes the urban policy objectives in large housing areas (social mix, trivialisation of these neighbourhoods, diversifying housing types...).

Secondly, it exposes the architectural ambitions in these projects and their possible innovations.

Finally, with the social representations of the renewed districts, we can assess whether this policy actually helps to make social housing neighbourhoods attractive and whether these are areas people want to live or a place that people put up with.

The question is whether the innovation and the architectural, ecological, environmental quality of the buildings and of the equipment in these projects attractive enough to change the social representations of large housing districts.

Identifying these representations enables us to understand how they are constructed and transformed and also to assess the impact of the urban policy interventions on the urban and architectural forms. Social representation becomes an assessing tool but also an action tool in neighbourhood renewal projects, fostering a participatory approach.

\section{The objectives of urban renewal in France: improving the inhabitants' living environment and making attractive neighbourhoods}

\subsection{Large housing areas in question}

The term "large housing area" ("grand ensemble") appeared for the first time in the title of an article by town planner Maurice Rotival in 1935. The article was concerned with social housing, more precisely those located in Drancy-la-Muette, which had been built by architects Beaudouin and Lods in 1934. They are associated with town planning including green spaces, social housing and architectural modernity, opposing "residential leprosy".

The Muette estate is traditionally considered the first large housing scheme in France, consisting of five fifteen-storey towers and fully collective housing.

However in March 1973, a ministerial circular by Olivier Guichard, the Minister for Infrastructure, Housing and Transport, attempted to prevent the implementation of urban forms known as "large housing areas" and fight against social segregation through housing. It prohibited any construction larger than 500housing unit buildings. Consequently, the construction of large housing areas was abandoned.

The "urban renewal" initiated at the end of 2003 with respect to the Framework Act for Town Planning and Urban Renewal (called the "Borloo law") was a change in perspective to making towns. This policy left behind the rehabilitation of districts and focused on intensive restructuring operations, based on massive demolitions followed by various reconstructions, in order "to break the urban ghettos". The urban project was aimed at fundamentally transforming large housing areas. These areas have a high concentration of households in social and economic difficulties. This is the result of a degraded residential attractiveness, particularly due to low urban quality (mediocre public places, enclosing, lack of 
facilities) and to low architectural quality. Residents of these neighbourhoods are victims of a stigmatisation that makes living conditions difficult.

Urban renewal initiatives have been aimed at turning these districts into "ordinary" urban areas characterized by diverse functions and various housing types, openness and links with the rest of the city, public space, together with an improvement in the inhabitants' living environment. The main interventions have consisted of making quality residential areas which actually separate the public and private domains, and building new housing: architectural and statutory diversification, the layout concerning the creation of roads to make blocks or open up the area, some public facilities, such as schools or nurseries.

The urban renewal project should enable one to put an end to the physical isolation as well as the urban degradation or downgrading of these districts. It should also help to integrate them into the rest of the city, to improve the inhabitants' quality of life and through the restructuring of the districts and the evolution of the organisations related to urban proximity management (Figure 1).

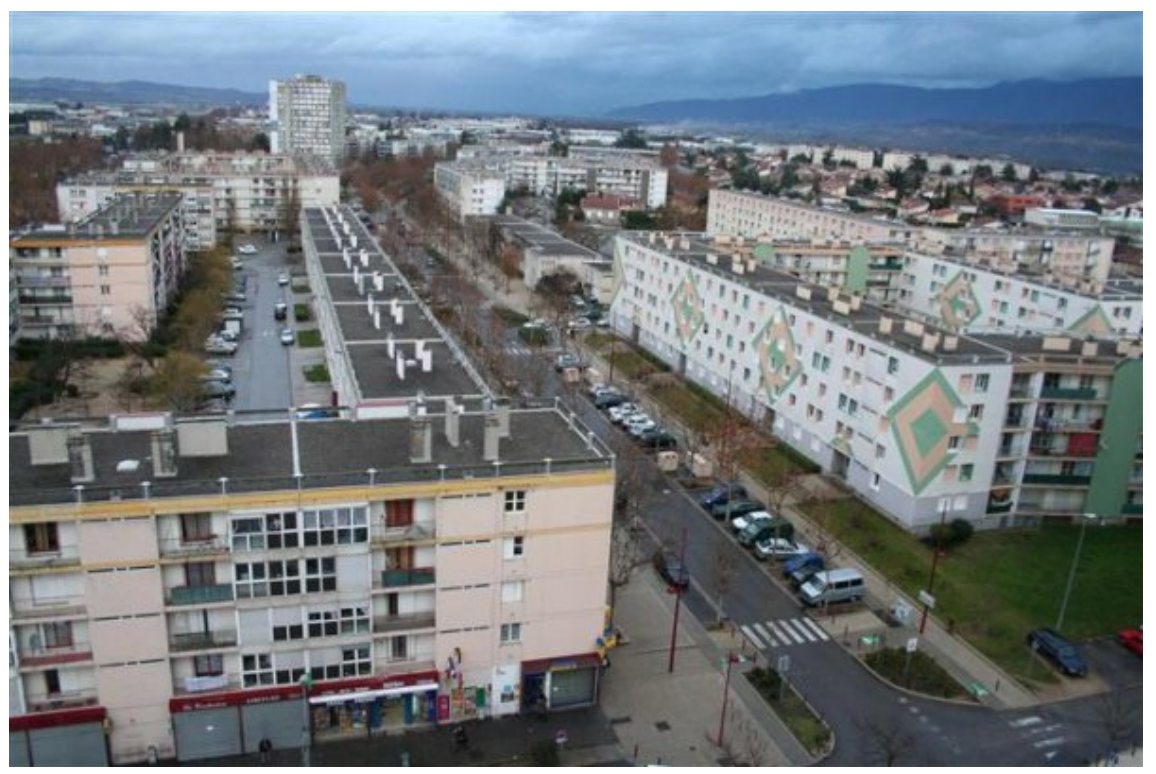

Figure 1: La Monnaie neighbourhood, Romans-sur-Isère, France.

\subsection{The renewed districts as pools of architectural and urban innovation}

\subsubsection{Architectural ambitions and innovations}

"The architectural, ecological, environmental quality of buildings and facilities" is one of the main criteria to assess urban renewal projects selected by the general regulation of projects. The image conveyed by the new operations is indeed a major lever for action in the success of the National Urban Regeneration Programme (PNRU): urban, architectural and landscape quality makes it possible to develop new contacts with the site, the public space, the buildings and housing. 
Moreover, improving the living environment is a major factor to make districts attractive and to reposition them within the cities. Lastly, the selected architectural options can contribute to standardise these frequently stigmatized districts and to integrate them better within their urban environment (Figure 2).

Diversifying housing, as it is recommended, is about diversifying housing statuses and architecture. On this latter point, important issues in renewal plans include varied and increasing urban forms (association of buildings with varied heights and volumes), diverse frontages (use of various materials, asymmetrical façades with more or fewer balconies and terraces), and multiple housing sizes (communal, semi-communal or individual).

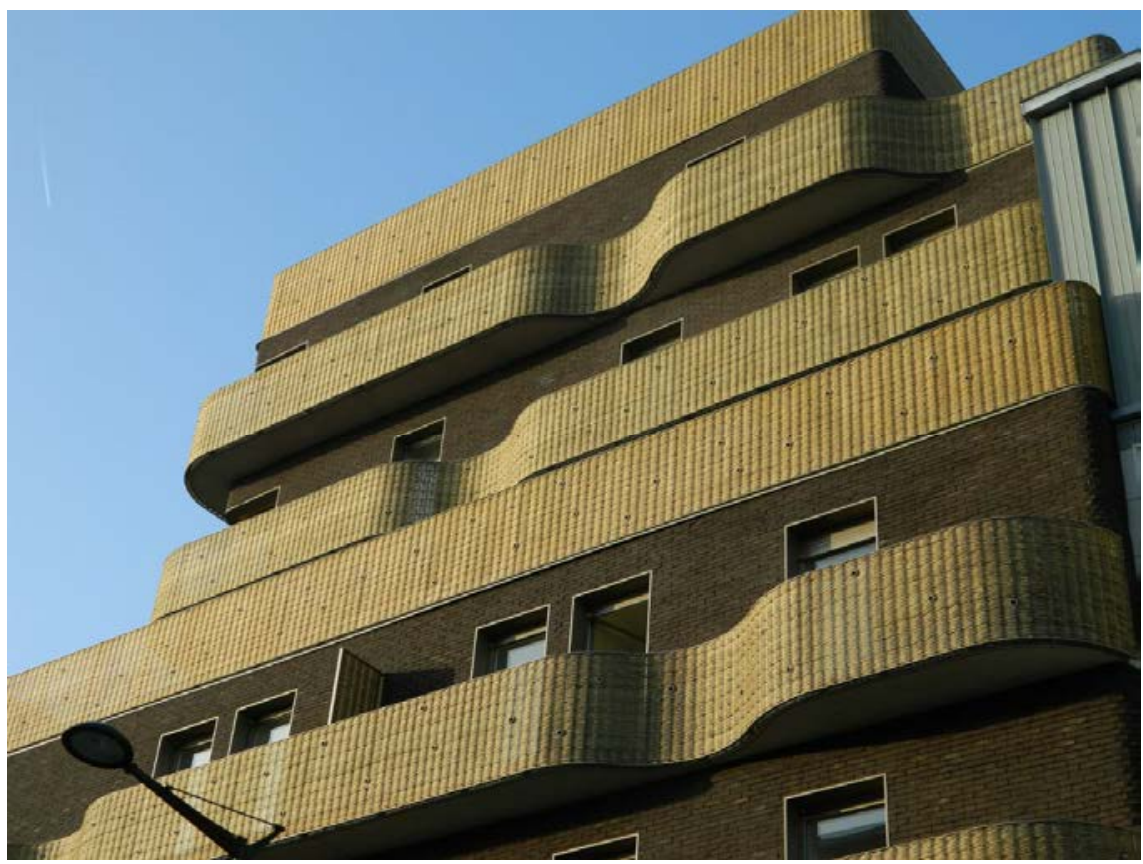

Figure 2: Le Candide, Vitry sur Seine, France (architect: B. Rollet).

\subsubsection{Social landlords' positions}

Even if the economic aspect of the operations is taken into account by social landlords, it is not their priority. Social landlords own the housing and wish to develop a patrimonial long-term approach which must take into account the sociodemographic characteristics of the tenant. Social landlords may choose cheaper aesthetics, but pay more attention to uses. A lot of architects claim to have more freedom in the design of social housing than in private housing. They very often have more flexibility to present innovative ideas when designing social housing. 


\subsubsection{The integration of sustainability issues to new operations}

The High Environmental Quality approach is enforced by means of a significant number of regulations and calculation methods, which enables to obtain labels: High Energy Efficiency, Very High Energy Efficiency, and Low Consumption Building. The major trend today is the use of identified systems such as solar energy for domestic hot water, rainwater harvesting for watering gardens, exterior insulation, bioclimatic housing positioning, green roofs, heat pumps and doubleflow ventilation systems. The constructive, architectural and urban answer to sustainability in housing projects generates specific and recognizable forms.

\subsubsection{The attraction of individual housing}

Finally, a general trend, regardless of the social classes concerned, shows a strong attraction to individual housing, which indeed fits in with an upward housing history and represents completion for a good number of tenants. To meet this overwhelming demand, but also to diversify architectural forms in order to break with the urban forms in large housing areas, there has been a growing number of small multiple-dwelling and single-dwelling housing on the large rebuilding lands with urban renewal projects.

Even if it is an overall trend, the conditions linked to rare and expensive property make the production of individual housing more complicated. To meet users' requirements while overcoming the property constraints, some town operators favour the construction of collective housing which looks like individual dwellings (asymmetrical and distinctive façades, private entrances, etc.).

New units have smaller sizes and volumes and stand along streets. They usually comply with a common architectural code, which helps to build unity in these varied forms and also within the close cityscape.

Thus, the monumentally large housing areas that broke with the rest of the city are being replaced by operations with more humble forms and a low profile, which make it possible to cross the boundaries between the districts and their cities. These architectural choices obliterate the stigma in the districts and seem to produce positive effects on their inhabitants, who mostly feel they no longer "live in the ghetto".

\subsubsection{The concept of large housing area heritage}

It has often been determined that it is not easy to convert the structure of large housing areas and that their demolition seems to be the best solution. However, the destruction of towers and low-rise buildings has caused a great deal of excitement among the inhabitants of these districts as well as among some architects and town planners. The issue of reconstructing large housing areas must now be considered [3]. Urban designers Yves Lion, Bernard Paris, Rémi Papillault, Alexandre Chemetoff and also Roland Castro agree with Bruno Vayssière's thinking about "Hard French" - he has actually been supporting the idea of patrimonialising large housing areas for a few years.

In her article "demolition" [4], Françoise Choay quotes Freud with these words "The peaceful development of any city involves demolitions". Demolition is "a historical necessity". In the same article, Françoise Choay also shows that if 
demolition sometimes appears as an almost cultural necessity, the legitimate condition of this act is "to have at your disposal the expertise that insures rebuilding". Demolishing and preserving work together in the act of building. That is why taking action in these areas is an extraordinary tool to innovate, to invent, to improve, and to rebuild. Some town planners have managed to seize this opportunity. For example, Druot and Lacaton Vassal Associates go into rehabilitation with forms, constructive systems, and also the innovative concept of coming to terms with the current organisation and of using its positive aspects, on a sustainable, resource-saving and innovative basis.

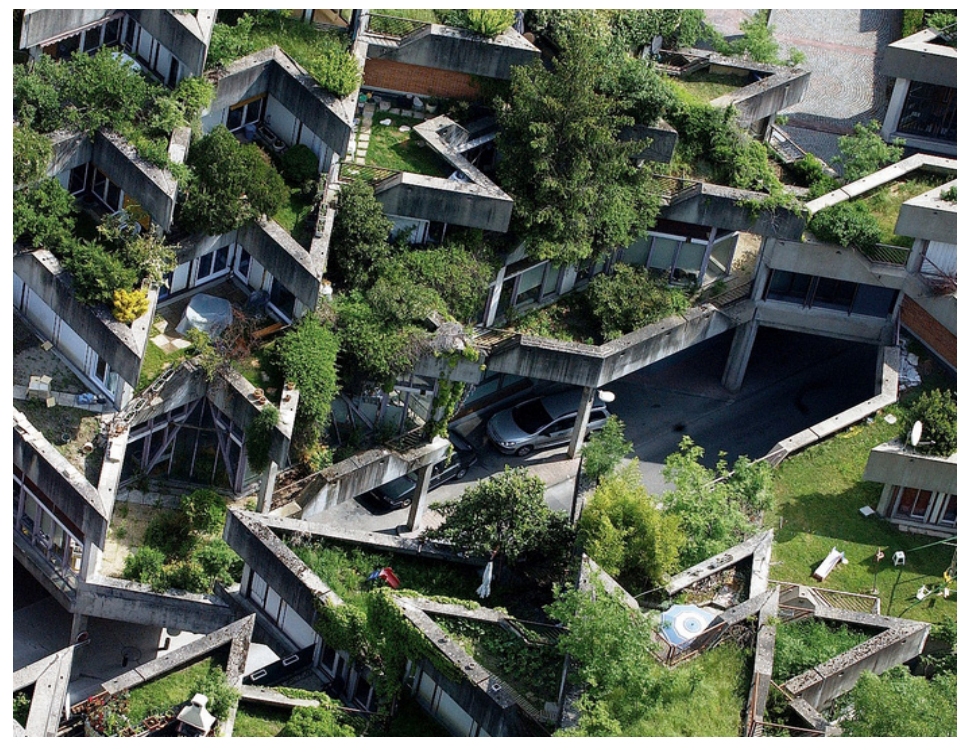

Figure 3: The heritage label "Cité de l'Etoile", Givors, France. (Architect: J. Renaudie.)

Castro Denissof Associates pay constant attention to functional quality and are convinced that new, more open and more spacious living spaces must be invented. Castro Denissof Associates get familiar with the areas so as to restructure them better, providing original and innovative formal solutions: cutting the tops of buildings, expanding, adding façade elements, rezoning.

We can observe that the challenge concerning the quality of urban projects has not been won everywhere yet, however, a new generation is going into action to think about the solutions to be provided in renewing large housing areas. 


\section{First assessments of urban policy: is urban renewal effective enough to make social housing districts attractive?}

\subsection{First assessments of the urban policy between 2003 and 2013}

One of the major challenges presented by urban renewal is how to redevelop neighbourhoods in a sustainable way to improve the inhabitants' living environment, through renovating, regenerating, restructuring, and adopting a sustainable development approach.

The urban policy from 2003 has striven to bring a solution to social problems in large housing areas through an exemplary physical intervention. "If the success of the National Urban Regeneration Programme (PNRU) can thus be presented as undeniable, it is firstly because its achievements are visible and proportionate to how spectacularly the traces of the past have disappeared in a cloud of dust and a smell of powder" [5].

When the urban renewal was completed, the assessments made by CES ANRU (Comité d'évaluation et de suivi de l'Agence nationale pour la Rénovation Urbaine - Assessment and Follow-up Committee for the National Agency for Urban Renovation) have shown that most inhabitants are satisfied. There is a noticeable change in the inhabitants' living environment. They have the feeling that they are safer, that they no longer live in a "ghetto"... New confidence in their position within the city seems to have been gained [6]. But whether these changes are permanent is uncertain, because there has been rising social brittleness among the inhabitants. For public actors, urban renovation makes it possible to solve the problems of suburbs. It creates an opportunity to take care of a stigmatized heritage and to revamp the territory. It is possible for social landlords to refresh the social composition of the residences and also to re-evaluate their heritage. Architects and town planners break new ground in the use of materials, in the types of housing units, or in the treatment of public areas.

However, the urban approach is sometimes very "formal" (for example, when the layouts of the ways and of the urban scheduling are only visible on the ground plans). The projects seem to provide architectural responses which do not take into account the specific characteristics of the districts, and without actually consulting the inhabitants.

\subsection{Social representation as a tool to assess how attractive renewed districts are}

Social representations are organized and prioritized sets of judgments, attitudes and information, which a given social group develops about a given object [7].

They are a subjective vision of reality, the content of which can be mobile and evolve according to the social or economic context, and also according to the influence of social relationships. Social representations are the subject of observations and reflections, to understand the link between people and their districts, and to act in the urban project through them. 


\subsubsection{Dangerous districts?}

Two large housing districts located in Grenoble and Echirolles in the Rhône-Alpes region in France are currently the subject of studies about social representations in connection with the urban renewal project carried out between 2003 and 2013 [8]. Their urban forms are characteristic of large housing areas. The demolition of numerous buildings has cleared the land necessary to develop new programs, new public spaces and facilities. The reputation of being "dangerous districts" has impacted the neighbourhoods and at the same time stigmatized their population. Within Village 2 district in Echirolles, there is a partition between the northern and southern areas - the latter has been highly stigmatized and considered as even more dangerous. This partition refers to a physical and architectural reality: the entrance to the district is located in the North and the southern area ends in a dead end. Due to these characteristics of the neighbourhood, it is sometimes referred to as the "end of the world", or "slums".

Young people's offences are often directly linked to the negative reputation of the district. However, the delinquency is put into perspective in view of other areas referred to as much more dangerous "hot districts".

Urban renewal initiatives have helped in the transformation of the physical appearance of the two districts with the purpose of changing their representations as dangerous areas.

New housing is offered to inhabitants from the district but the goal is to attract new people by social home ownership, and thus to bring social mixing.

In Village 2 district in Echirolles, the new housing program represents 176 housing units spread over four buildings, among which two offer social home ownership (54 units).

In the Teisseire estate in Grenoble, the main tool for the diversification policy in the district has resulted in the creation of an expansion welcoming new housing transactions, i.e., 460 units, 80 percent of which offer social home or free ownership. The profile of the area has evolved from 100 percent to 75 percent of social housing. The social home ownership housing stock is quite attractive to newcomers. Social mixing implicitly appears in the urban project. Indeed, it is a challenge to enable a population with a more varied and less precarious socioprofessional profile to purchase a dwelling.

Is suggesting purchasing an attractive dwelling (taking into consideration the fact that the land is expensive, but the area is stigmatized), enough to draw new inhabitants?

To assess how attractive it is, the social representations gathered from the newcomers make it truly possible to determine the impact of the urban project on the representation of these districts and to understand what drives these people to move in.

The visual change of the area is not the main reason for the new inhabitants to settle there. The cost of the housing is the primary motivation. The second reason is the fact that the new housing is built at the edge of the district.

The new inhabitants share the collective negative representations of the district but have come to settle near the border, considering that they are not part of the rest of the district. 


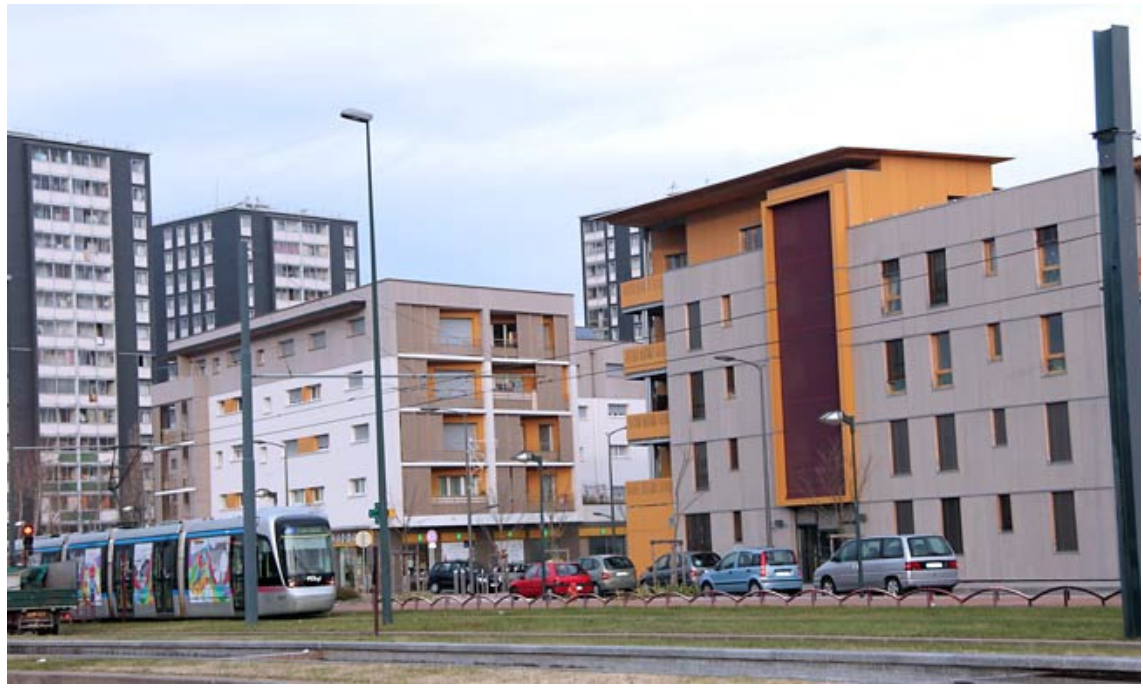

Figure 4: Village 2 Echirolles - after urban renewal.

\subsection{Taking into account the social representations of districts in urban projects}

It seems appropriate to collect the representations of the district from this distinctive category of people because it is agreed that the "old" inhabitants' living environment has improved, even if social issues remain.

Interviewing and filling in questionnaires with newcomers make typical representations come out - this is completed by the data collection from the district barometers and other surveys about the district population or assessments financed by Grenoble conurbation.

The first step is meant to develop a terminology suitable to each studied area. Typical representations are then organized into two groups; the first group gathering social representations connected to the built environment and the second bringing together those connected to social life.

Typical social representations relating to the built environment deal with visible physical degradations, urban form (e.g., the "tower" as a symbol of the depreciation of these areas), physical isolation or privacy.

Typical representations relating to social life deal with social vacuum, economic and social depreciation, the feeling of a declining district, and insecurity.

Identifying the representations used by the locals leads to checking whether there is a mechanistic relationship between urban forms and social representations. These representations can help to develop an urban project, in tune with the inhabitants' expectations. Working on urban form means erasing a stigmatized architecture. Replacing towers by low-rise buildings amid quality public spaces gives the feeling of living in a "residential" district. Uniting and homogenizing at city level make districts commonplace. 
In view of social vacuum, local community life can be developed. Encouraging and enabling residential mobility reduce the sense of ghettoization.

These actions tend to modify and change the social representations of these districts in order to stop their depreciation, to offer a better living environment for the inhabitants and to attract a less precarious population.

\section{Conclusions}

The urban renewal started in 2003 has not been a trivial matter. It has been at the centre of political debates and the subject of numerous books on sociology, town planning, and architecture. It has been an issue or has brought about consensus.

The interventions in large housing areas have been spectacular and staged to legitimate political action approved by the majority.

Most acknowledge that the urban policy has truly changed the inhabitants' "material" living conditions, and has often succeeded in making such districts commonplace, so that they appear attractive.

The urban renewal project has enabled the making of residential areas, to implement rehabilitations, to build new housings and to enhance public spaces. Referring to the classical city register, the interventions have aimed at making the neighbourhoods commonplace, in order to put an end to the physical isolation of these districts on the one hand, and to open them up to a less precarious population on the other hand (newly constructed housing programmes and social housing allocation policy).

The question is if these changes have been accompanied by new representations.

Work about identifying typical representations has been done by means of conducting interviews with newcomers and analysing their contents. This identification can be drawn closer and confronted to the political and mediatised representations that go along with the urban project. This collection makes typical representations appear, in connection with the built framework, well-being, and everyday life, but also with social ties within the neighbourhood.

Identifying representations makes it possible to implement target actions in districts and to improve the urban project.

Achieving the goal of social mixing primarily means attracting a new population. To do this, the intervention in the district should be based on existing social representations, and should analyse their content to have an effect on what they are constructed from. The outcome is to change the frequently negative representation about the district and to make it attractive enough for new inhabitants to wish for private ownership. So as to make the neighbourhood attractive, work must be done about representations concerning urban and social depreciation (declining district, ghetto, economic and social depreciation, insecurity...). The means are rehabilitating, uniting, regenerating with new buildings, developing social life in the district, social heterogeneity, and finally the inhabitants' taking the spaces over.

This work can only be done in close cooperation with the inhabitants and must be based on the speech emerging from districts. 
Areas like Teisseire are so stigmatised, despite an innovative urban project that it is necessary to come back to these representations to think about urban interventions in a different way. Since the urban policy was implemented, districts have had difficulty in changing their image. Acting on the built framework only has not proved effective enough.

That is why the new urban policy, which started in 2014, has indeed been taking into consideration the need to integrate the citizens in the urban project, in order to guarantee its success and a lasting future. It has put in place consultation tools such as citizen councils, the project house, participatory workshops, but the idea of translating social representations or the inhabitants' voice into the urban project is still sensitive.

\section{References}

[1] Rivière, J. \& Tissot, S., La construction médiatique des banlieues. Retour sur la campagne présidentielle de 2007. Métropolitiques, 7, 2012. www.metropolitiques.eu/La-construction-mediatique-des.html.

[2] Bertho, R., Les grands ensembles, 2014. http://etudes photographiques. revues.org/3383.

[3] Review "Urbanisme" about town planning, 388, 2013.

[4] Review "Urbanisme” about town planning, 386, 2011.

[5] Epstein, R., ANRU: Mission accomplie? A quoi sert la rénovation urbaine? ed. J. Donzelot, PUF: Paris, 2012.

[6] Allen, B. \& Duret, H., A quoi sert la rénovation urbaine? ed. J. Donzelot, PUF: Paris, 2012.

[7] Garoscio, A., Représentations sociales de l'insécurité en milieu urbain. Les Cahiers Internationaux de Psychologie Sociale, 1, 2006.

[8] Evaluation du programme cadre de la politique de rénovation urbaine de Grenoble-Alpes Métropole Teisseire et Village 2. 